\title{
EVALUATION OF THE JOB SATISFACTION LEVELS OF THE PERSONNEL WHO WORKED IN SPORTS ORGANIZATION
}

\author{
Gul CAVUSOGLU, M. Yalcın TASMEKTEPLIGIL, Izzet ISLAMOGLU,
}

\section{Saban UNVER}

${ }^{1}$ University of Ondokuz Mayıs, Faculty of Yasar Dogu Sports Sciences, 55139, Samsun, Turkey

1'gul.cavusoglu@omu.edu.tr, ${ }^{2}$ myalcint@gmail.com, ${ }^{3}<$ izzetislamoglu@gmail.com>, ${ }^{4}$ saban.unver@omu.edu.tr

\begin{abstract}
The aim of the study was to determine the job satisfaction levels of the personnel who worked in sports organization. 285 randomly selected people who worked in sports organization participated in this study. A form for personal information and Minnesota Job Satisfaction Scale (MSQ) developed by Weiss et al (1967) and checked for validity and reliability by Baycan (1985) were used in the study. Mann-Whitney U, Kruskal-Wallis $\mathrm{H}$ and Dunn's multiple comparison tests were used for the analysis of the data. A significant difference was found among the groups in terms of their job satisfaction scores with increasing age in the statement of wages eamed for the profession. Satisfaction levels in tems of wages showed significant difference as the educational levels of personnel decreased. It was stated that the personnel whose job satisfaction levels were generally moderate were not pleased in tems of payment and the chances for advancement. However, the personnel's job satisfaction scores' being moderate shows that payment alone does not affect job satisfaction.
\end{abstract}

\section{Keywords}

Job satisfaction, personnel, sport organization

Academic Discipline And Sub-Disciplines

Sport Management

SUBJECT CLASSIFICATION

Social Science

TYPE (METHOD/APPROACH)

Survey

\section{Council for Innovative Research}

Peer Review Research Publishing System

\section{Journal: Journal of Social Sciences Research}

Vol. 9, No. 2

jssreditor.cir@gmail.com

www.jssronline.com 


\section{INTRODUCTION}

In the dynamics between an organization and its employees, it has been said that "the lifeblood of an organization is the human resources that it employs" (Hurd et al., 2008). Human resource management is a management function within an organization that develops and implements the policies and procedures affecting the people in the organization: from recruitment and retention to personal development and training.

Job satisfaction is the emotional response showed by the personnel for their roles at their work. The positive reaction shown to work is called job satisfaction while negative reaction is called job dissatisfaction (Chen, 2007). Job satisfaction is comprised of many intrinsic and extrinsic dimensions and can be impacted by a broad range of personal and job related factors and issues (Volkwein and Zhou, 2003). Job satisfaction is often related to employee attitudes or feelings about their job. A number of researchers further suggest that job satisfaction is "best viewed as a collection of attitudes about difference aspects of the job and work context" (McShane and Steen, 2009).

The research is important in terms of helping to reveal the needs of the personnel working in sports organizations and finding out the deficiencies. This study will play a key role in detemining what managers need in order to increase the satisfaction of the personnel based on the findings gained and in contributing to the literature in this context. Accordingly, the purpose of the study in question is to detemine the job satisfaction perceptions of the personnel satisfied and dissatisfied with their job by identifying job satisfaction levels of the personnel working in sports organization. Thus, it can be possible to offer some suggestions on how to improve the effectiveness of job satisfaction of the personnel in related institutions by presenting on which variables the job satisfaction of the personnel becomes different.

\section{MATERIAL AND METHOD}

The study group of the research are randomly selected managers, gymnasts, officials and technical staff working in sports organization (Aydın, Bolu, Erzincan, Eskişehir, Gaziantep, Kayseri, Kütahya, İstanbul, Mersin, Rize, Samsun, Şanlıurfa) in 2014 ( $\mathrm{N}=285)$. An identification form questioning the personal characteristics of the personnel and Minnesota Job Satisfaction Scale (MSQ) which was translated and the validity and reliability studies of which were conducted by Baycan (1985) and which was developed by Weiss et al (1967) in order to measure the job satisfaction were used in the study (Cronbach Alpha=0.77). In this study, internal consistency coefficient total was found as 0.92 , external satisfaction as 0.82 and internal satisfaction as 0.89 . Minnesota Job Satisfaction Scale in which the participation level is detemined by responding in Likert-style consists of 20 items which determine intemal dimension $(1,2,3,4,7,8,9,10,11,15,16,20)$, external dimension $(5,6,12,13,14,17,18,19)$ and overall level of satisfaction.

In the study, first, descriptive statistics of the personal data of the participants were made, then nomality assumption of the data was examined with Shapiro-Wilk test $(p<0.05)$. Since the nomality assumption was not provided, Mann-Whitney $U$ test was used to determine differences between the two groups, Kruskal-Wallis was used for three and more groups and Dunn's multiple comparison test was used to detemine the differences between group averages. Findings were considered significant at $\mathrm{p}<0.05$ level. All statistical analys is was carried out in MINITAB and SPSS 21 software program.

\section{Ethical Considerations}

Before the study, the required ethics committee approval by Mersin University (2013/396) and written permission by the consents of the participants' were obtained. The aim of this study was explained to the subjects during the data collection phase, and thus the "informed consent principle" was fulfilled.

\section{FINDINGS}

The findings of the study are presented in tables below.

Table 1. Distribution of job satisfaction scores according to some socio-demographic characteristics of employees

\begin{tabular}{|c|c|c|c|c|c|c|c|c|c|}
\hline \multicolumn{2}{|l|}{ Variables } & \multicolumn{4}{|c|}{ Internal Satisfaction } & \multicolumn{4}{|c|}{ External Satisfaction } \\
\hline \multirow{4}{*}{ Gender } & & Medyan & IQR & Min & Max & Median & IQR & Min & Max \\
\hline & Male & 44 & 12 & 13 & 60 & 26 & 9 & 10 & 40 \\
\hline & Female & 45 & 12,25 & 18 & 60 & 25 & 9 & 8 & 40 \\
\hline & $\mathbf{P}$ & \multicolumn{4}{|c|}{0,456} & \multicolumn{4}{|c|}{0,930} \\
\hline \multirow{3}{*}{ Marital status } & Married & 44 & 12 & 13 & 60 & 26 & 10 & 8 & 40 \\
\hline & Single & 44 & 11 & 18 & 60 & 26 & 9 & 10 & 40 \\
\hline & $\mathbf{P}$ & \multicolumn{4}{|c|}{0,738} & \multicolumn{4}{|c|}{0,622} \\
\hline \multirow{2}{*}{ Age } & $20-30$ & $42^{a}$ & 12 & 18 & 59 & $25^{a}$ & 9 & 10 & 40 \\
\hline & $31-40$ & $44,5^{a}$ & 15 & 19 & 60 & $26^{a}$ & 10,5 & 8 & 38 \\
\hline
\end{tabular}




\begin{tabular}{|c|c|c|c|c|c|c|c|c|c|}
\hline & $41-50$ & $47^{\circ}$ & 10 & 24 & 60 & $29^{\circ}$ & 8 & 14 & 40 \\
\hline & $>50$ & $45,5^{\mathrm{ad}}$ & 19 & 13 & 50 & $29,5^{0}$ & 15,25 & 10 & 32 \\
\hline & $\mathbf{P}$ & \multicolumn{4}{|c|}{0,013} & \multicolumn{4}{|c|}{0,014} \\
\hline \multirow{4}{*}{ Education } & High school & $47 a$ & 13 & 24 & 60 & $30 a$ & 9 & 14 & 40 \\
\hline & $\begin{array}{l}\text { Associate } \\
\text { Degree }\end{array}$ & $47^{a b}$ & 10 & 13 & 55 & $28^{a b}$ & 9,5 & 10 & 35 \\
\hline & $\begin{array}{l}\text { Bachelor's } \\
\text { degree and } \\
\text { above }\end{array}$ & $43 b$ & 12 & 18 & 59 & $25 b$ & 9 & 8 & 38 \\
\hline & $\mathbf{P}$ & \multicolumn{4}{|c|}{0,021} & \multicolumn{4}{|c|}{0,003} \\
\hline \multirow{4}{*}{ Income level } & $0-1000$ & 41 & 12 & 28 & 60 & 24 & 4 & 15 & 39 \\
\hline & $1001-2000$ & 44 & 12 & 18 & 60 & 26 & 9 & 10 & 40 \\
\hline & $>2001$ & 44 & 10,5 & 13 & 57 & 27 & 10 & 8 & 37 \\
\hline & $\mathbf{P}$ & \multicolumn{4}{|c|}{0,962} & \multicolumn{4}{|c|}{0,621} \\
\hline \multirow{5}{*}{$\begin{array}{c}\text { The reason } \\
\text { for choosing } \\
\text { the job }\end{array}$} & Environment & $42^{a}$ & 11,25 & 26 & 54 & 24 & 9,25 & 16 & 33 \\
\hline & $\begin{array}{l}\text { Occupational } \\
\text { expectations }\end{array}$ & $42^{\mathrm{a}}$ & 12 & 13 & 60 & 26 & 9 & 10 & 40 \\
\hline & $\begin{array}{l}\text { Socio-economic } \\
\text { characteristics }\end{array}$ & $43^{a}$ & 15 & 20 & 60 & 22,5 & 9 & 14 & 39 \\
\hline & Personality & $48^{\circ}$ & 9 & 19 & 60 & 28 & 9 & 8 & 40 \\
\hline & $\mathbf{P}$ & \multicolumn{4}{|c|}{0,001} & \multicolumn{4}{|c|}{0,194} \\
\hline \multirow{3}{*}{$\begin{array}{l}\text { The state of } \\
\text { doing sports }\end{array}$} & Yes & $45^{a}$ & 12 & 20 & 60 & 26,5 & 8,25 & 10 & 40 \\
\hline & No & $43^{\circ}$ & 13 & 13 & 59 & 26 & 9 & 8 & 40 \\
\hline & $\overline{\mathbf{P}}$ & \multicolumn{4}{|c|}{0,049} & \multicolumn{4}{|c|}{0,421} \\
\hline
\end{tabular}

Score differences between groups were not found statistically significant ( $p>0.05$ ) when the intemal and external satisfaction scores of employees were analyzed in terms of gender and marital status (Table 1). However, the difference between the groups was found statistically significant in terms of age, education, income level, the reason for choosing the job and the state of doing sports $(p<0.05)$.

Table 2. Job satisfaction levels in terms of age and the reason for choosing the job

\begin{tabular}{|c|c|c|c|c|c|c|c|c|c|c|c|c|}
\hline & \multirow{2}{*}{ Items } & \multirow{2}{*}{ SL } & \multicolumn{2}{|c|}{$20-30$} & \multicolumn{2}{|c|}{$31-40$} & \multicolumn{2}{|c|}{$41-50$} & \multicolumn{2}{|c|}{$>51$} & \multirow{2}{*}{$x^{2}$} & \multirow{2}{*}{$p$} \\
\hline & & & $\mathrm{n}$ & $\%$ & $n$ & $\%$ & $n$ & $\%$ & $\mathrm{n}$ & $\%$ & & \\
\hline \multirow{5}{*}{ Age } & \multirow{5}{*}{$\begin{array}{c}\text { I.1 } \\
\text { Being able to } \\
\text { keep busy all the } \\
\text { time }\end{array}$} & 1 & 7 & 5,0 & 4 & 5,1 & 1 & 1,8 & 3 & 25,0 & \multirow{5}{*}{22,604} & \multirow{5}{*}{0,031} \\
\hline & & 2 & 24 & 17,1 & 13 & 16,7 & 3 & 5,5 & 1 & 8,3 & & \\
\hline & & 3 & 21 & 15,0 & 13 & 16,7 & 5 & 9,1 & 0 & 0,0 & & \\
\hline & & 4 & 76 & 54,3 & 43 & 55,1 & 37 & 67,3 & 7 & 58,3 & & \\
\hline & & 5 & 12 & 8,6 & 5 & 6,4 & 9 & 16,4 & 1 & 8,3 & & \\
\hline & & & \multicolumn{2}{|c|}{$\begin{array}{c}\text { Environ } \\
\text { ment }\end{array}$} & \multicolumn{2}{|c|}{$\begin{array}{c}\text { Occupatio } \\
\text { nal } \\
\text { expectatio } \\
\text { ns }\end{array}$} & \multicolumn{2}{|c|}{$\begin{array}{c}\text { Socio- } \\
\text { economic } \\
\text { characterist } \\
\text { ics }\end{array}$} & \multicolumn{2}{|c|}{ Personality } & \multirow{4}{*}{24,886} & \multirow{4}{*}{0,015} \\
\hline & & & $\mathrm{n}$ & $\%$ & $\mathrm{n}$ & $\%$ & $\mathrm{n}$ & $\%$ & $\mathrm{n}$ & $\%$ & & \\
\hline \multirow{2}{*}{$\begin{array}{c}\text { The } \\
\text { reason for } \\
\text { choosing }\end{array}$} & \multirow{2}{*}{$\begin{array}{c}.2 \\
\text { The chance to }\end{array}$} & 1 & 0 & 0,0 & 22 & 14,3 & 3 & 10,0 & 2 & 2,7 & & \\
\hline & & 2 & 4 & 15,4 & 23 & 14,9 & 4 & 13,3 & 10 & 13,3 & & \\
\hline
\end{tabular}




\begin{tabular}{|c|c|c|c|c|c|c|c|c|c|c|c|c|}
\hline \multirow[t]{18}{*}{ the job } & \multirow{3}{*}{$\begin{array}{l}\text { work alone on } \\
\text { the job }\end{array}$} & 3 & 6 & 23,1 & 34 & 22,1 & 7 & 23,3 & 6 & 8,0 & & \\
\hline & & 4 & 15 & 57,7 & 63 & 40,9 & 14 & 46,7 & 46 & 61,3 & & \\
\hline & & 5 & 1 & 3,8 & 12 & 7,8 & 2 & 6,7 & 11 & 14,7 & & \\
\hline & \multirow{5}{*}{$\begin{array}{l}\text { I.3 } \\
\text { The chance to } \\
\text { do different } \\
\text { things }\end{array}$} & 1 & 1 & 3,8 & 16 & 10,4 & 1 & 3,3 & 1 & 1,3 & \multirow{5}{*}{23,526} & \multirow{5}{*}{0,024} \\
\hline & & 2 & 4 & 15,4 & 24 & 15,6 & 6 & 20,0 & 5 & 6,7 & & \\
\hline & & 3 & 6 & 23,1 & 23 & 14,9 & 10 & 33,3 & 10 & 13,3 & & \\
\hline & & 4 & 13 & 50,0 & 69 & 44,8 & 10 & 33,3 & 46 & 61,3 & & \\
\hline & & 5 & 2 & 7,7 & 22 & 14,3 & 3 & 10,0 & 13 & 17,3 & & \\
\hline & \multirow{5}{*}{$\begin{array}{c}\text { I.8 } \\
\text { The way the job } \\
\text { provides for } \\
\text { steady } \\
\text { employment }\end{array}$} & 1 & 4 & 15,4 & 8 & 5,2 & 3 & 10,0 & 3 & 4,0 & \multirow{5}{*}{22,385} & \multirow{5}{*}{0,033} \\
\hline & & 2 & 2 & 7,7 & 7 & 4,5 & 5 & 16,7 & 6 & 8,0 & & \\
\hline & & 3 & 6 & 23,1 & 15 & 9,7 & 5 & 16,7 & 12 & 16,0 & & \\
\hline & & 4 & 12 & 46,2 & 83 & 53,9 & 15 & 50,0 & 35 & 46,7 & & \\
\hline & & 5 & 2 & 7,7 & 41 & 26,6 & 2 & 6,7 & 19 & 25,3 & & \\
\hline & \multirow{5}{*}{$\begin{array}{l}\text { I.11 } \\
\text { The chance to } \\
\text { do something } \\
\text { that makes use } \\
\text { of their abilities }\end{array}$} & 1 & 0 & 0,0 & 25 & 16,2 & 2 & 6,7 & 4 & 5,3 & \multirow{5}{*}{30,547} & \multirow{5}{*}{0,002} \\
\hline & & 2 & 3 & 11,5 & 21 & 13,6 & 4 & 13,3 & 6 & 8,0 & & \\
\hline & & 3 & 11 & 42,3 & 23 & 14,9 & 8 & 26,7 & 9 & 12,0 & & \\
\hline & & 4 & 10 & 38,5 & 51 & 33,1 & 12 & 40,0 & 38 & 50,7 & & \\
\hline & & 5 & 2 & 7,7 & 34 & 22,1 & 4 & 13,3 & 18 & 24,0 & & \\
\hline
\end{tabular}

\section{1: Strongly dissatisfied 2: Dissatisfied $\quad 3:$ Neutral $\quad$ 4: Satisfied $\quad$ 5: Strongly satisfied}

\section{SL: Satisfaction Level}

"Being able to keep busy all the time" (Item 1) varied in terms of age $(p<0.05)$. The expressions "The chance to work alone on the job" (Item 2), "The chance to do different things" (Item 3), "The way the job provides for steady employment" (Item 8), "The chance to do something that makes use of their abilities" (Item 11) varied in terms of the reason for choosing the job $(p<0.05)$ in Table 2.

Table 3. Job satisfaction levels in terms of marital status and the state of doing sports

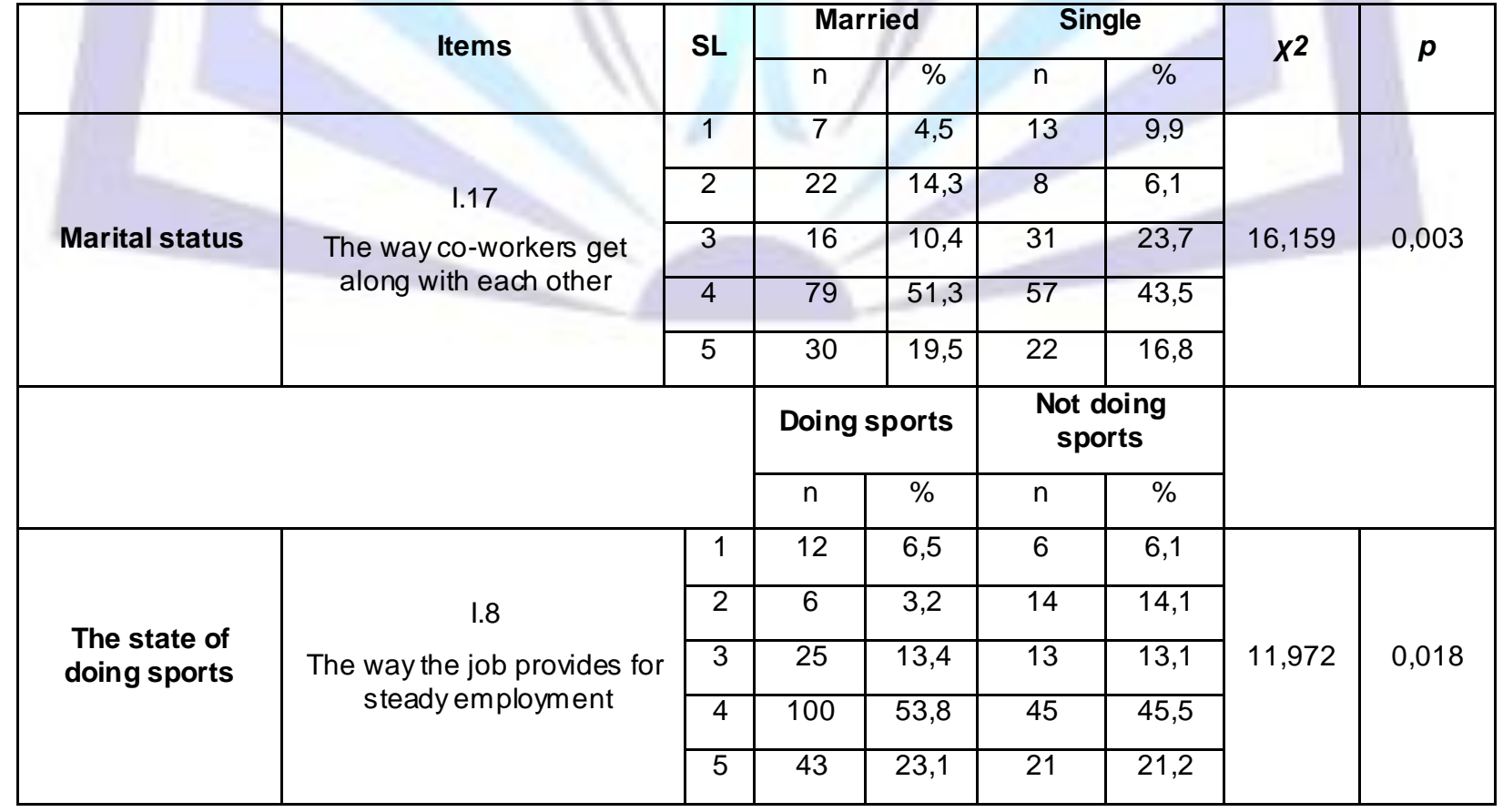


"The way co-workers get along with each other" (Item 17) varied in terms of marital status ( $p<0.05)$. "The way the job provides for steady employment" (Item 8 ) varied in terms of the state of doing sports $(p<0.05)$ in Table 3.

Table 4. Job satisfaction levels in terms of education

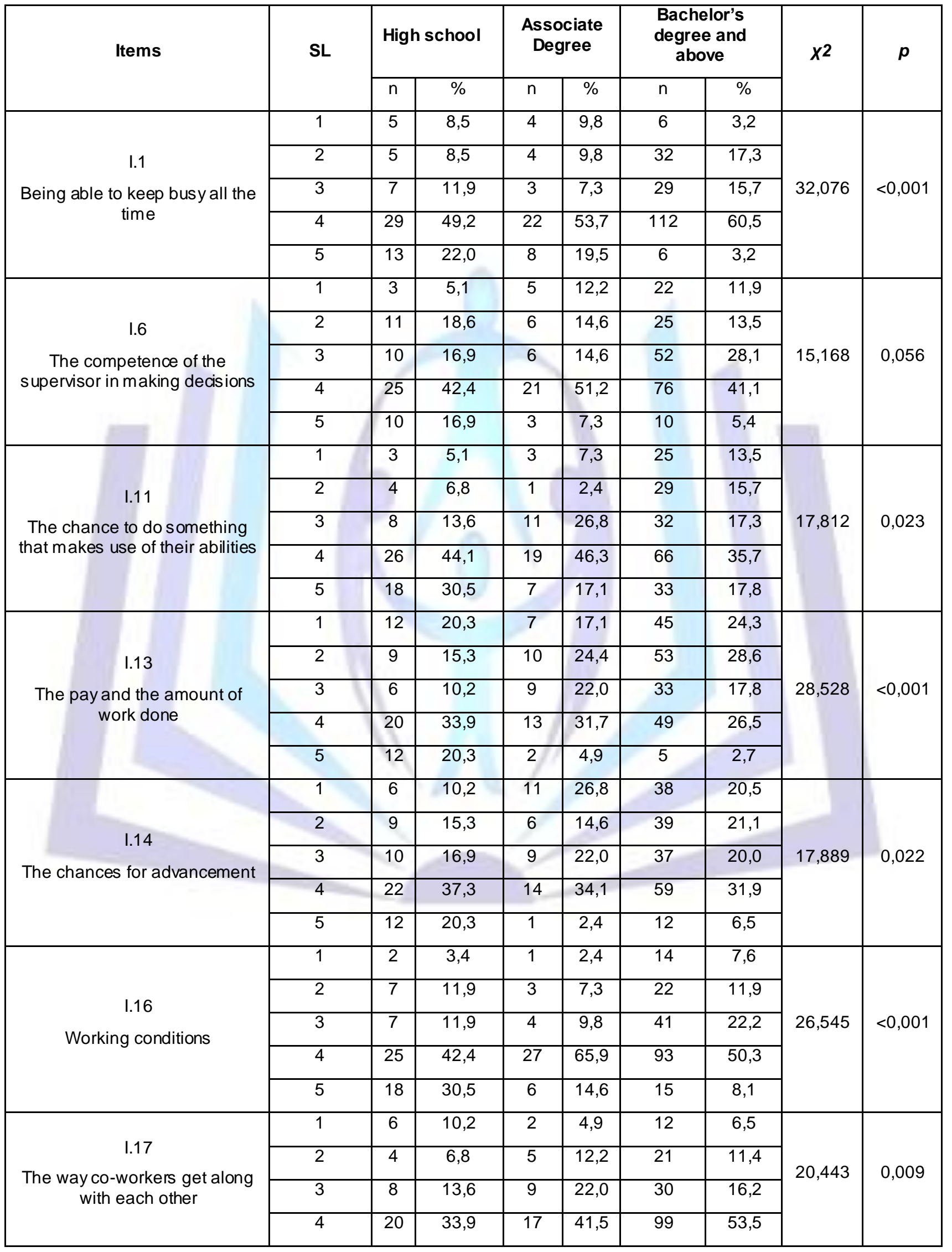




\begin{tabular}{|c|c|c|c|c|c|c|c|c|c|}
\hline & 5 & 21 & 35,6 & 8 & 19,5 & 23 & 12,4 & \\
\hline \multirow{3}{*}{$\begin{array}{c}\text { I.18 } \\
\text { Being appreciated }\end{array}$} & 1 & 6 & 10,2 & 3 & 7,3 & 19 & 10,3 & \\
\cline { 2 - 9 } & 2 & 6 & 10,2 & 7 & 17,1 & 33 & 17,8 & \multirow{3}{*}{31,240} \\
\cline { 2 - 9 } & 3 & 5 & 8,5 & 12 & 29,3 & 56 & 30,3 & \\
\cline { 2 - 9 } & 4 & 23 & 39,0 & 14 & 34,1 & 63 & 34,1 \\
\end{tabular}

In Table 4, when the job satisfaction levels of the participants were analyzed in terms of educational status, it was found that the expressions "Being able to keep busy all the time" (Item 1), The competence of the supervisor in making decisions" (Item 6), "The chance to do something that makes use of their abilities" (Item 11), "The pay and the amount of work done"(Item 13), "The chances for advancement "(Item 14), "working conditions" (Item 16), " The way co-workers get along with each other" (Item 17), "Being appreciated" (Item 18) showed difference $(p<0.05$ ).

Table 5. Job satisfaction levels in terms of income

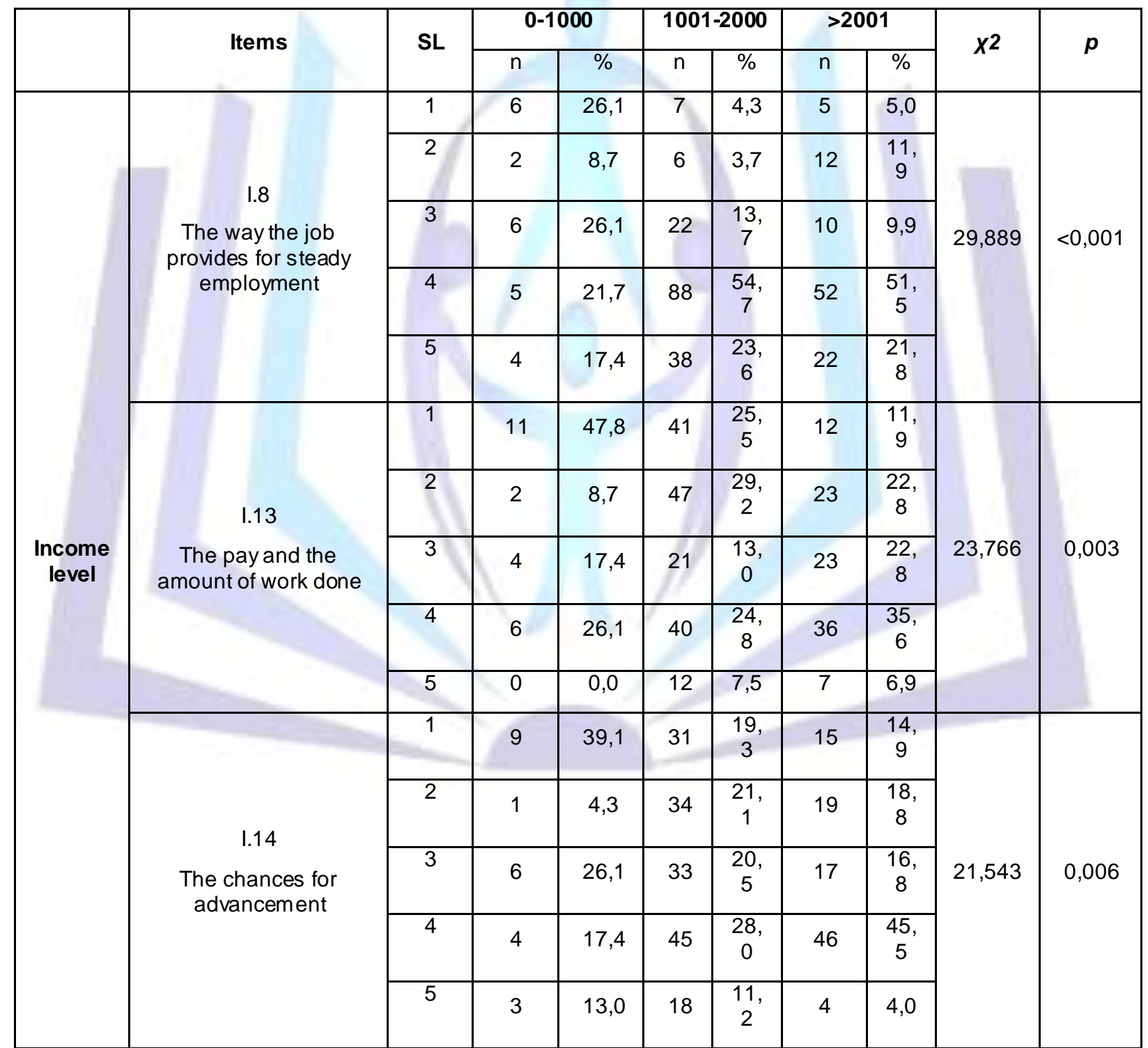

In Table 5, when the job satisfaction levels were analyzed in terms of income, it was found that the expressions "The way the job provides for steady employment" (Item 8), "The pay and the amount of work done"(Item 13) and "The chances for advancement "(Item 14) showed difference.

\section{DISCUSSION}


In this study, in which the job satisfaction levels of the provincial employees in Turkish sports organizations were searched, intemal and external scores were analyzed and the differences in scores between the groups were not found to be statistically significant in terms of the variables of marital status and income. In the evaluation of the employees' job satisfaction scores in tems of age, it was seen that the internal and external satisfaction scores increased with the increase in age. Schult and Schultz (1998) reported that job satisfaction increased with age whereas McKenna (2006) presented a significant difference between the employees' age and job satisfaction in their study. When the educational levels of employees was analyzed in terms of their internal and external satisfaction scores, the difference between groups was found statistically significant. As the educational level increased, intemal and external satisfaction scores dropped. According to Burris (1983), if a person's education level is higher than the requisites of his/her job, it creates job dissatisfaction; if the education level is moderately higher than what the job requires, the interaction between the two variables is little. This results from the subjective perceptions of the individuals that they are more qualified with regard to their jobs. When the job satisfaction scores of the employees were analyzed in terms of the reason for choosing the profession only internal satisfaction scores were statistically significant. The employees who expressed "personality" for the reason of choosing the profession have higher internal satisfaction scores than the other groups. It can be taken naturally that the difference arises from the internal satisfaction since the reason for choosing a profession is related to the individual himself. On the other hand, job satisfaction scores of the employees who did sports were found significantly higher in internal satisfaction category than those who did not do sports. This result may originate from the sport's influence to develop self-confidence and contribution to the development of self-respect.

A statistical variation was observed between some of the variables in the study and the MSQ items. According to this, item 1 can be said to be age dependent. Here, job satisfaction levels of the employees between 41-50 ages were found high in terms of "Being able to keep busy all the time" (item 1). This finding can be explained by the views that the lower age group has high expectations for the job and the job can not make them busy enough. It shows that what causes the decrease in the work performance and the disorder within the institution is that the young employees expressed that their job did not make them busy enough because of the changes in their interests. Experience obtained with age can change the results by affecting job satisfaction. Bos et al (2009) and Wilson et al (2008) found in their study that job satisfaction increased as age increased.

Choosing a profession is one of the most important choices to be made throughout a person's life. The person also chooses the environment to live, the economic situation in a sense and the people to be in relationship by choosing the profession (Yelboğa, 2008). In terms of the reason for choosing the profession; it is understood that the ones who preferred the option "personality characteristics" in terms of the expressions "independent work" (item 2), "to be able to do different things" (item 3 ) and "to be able to do something with their own talent" (item 11) and "professional expectations" option in terms of "The way the job provides for steady employment" (item 8) had the highest job satis faction scores. It can be thought as natural that the personality characteristics were effective in statements in question (Item 2, Item 3 and Item 11). It is considered that when the job is preferred based on the personality; this affects the job satisfaction of the employees significantly. It should be noted here that there is a strong connection between personality and career choice in terms of job satisfaction. On the other hand, that the option "The way the job provides for steady employment" had the highest percentage in the professional expectations option can be interpreted as the institutional expectations of the individuals are partly covered.

The results showed that married individuals had higher job satisfaction level in comparison with the single ones in terms of the expression "The way co-workers get along with each other" (Item 17). In literature, there are a number of studies supporting this finding (Erdem et al., 2008; Ünsar et al., 2006) as well as the studies asserting the contrary (Sünter et al., 2001; Aksu et al., 2002). High levels of job satisfaction that married people have may result from the reflection of the order of family life and peace on work. In other words, single employees' having low job satisfaction can be explained with the gradual reflection of undisciplined way of life and uneasiness on the job.

Exercise is very important for the protection and improvement of health. In his study, Akpınar (2010), analyzed the job satisfaction level of the employees in tems of the variable of doing sport and in the study it was stated that the job satisfaction level of the ones doing sport was higher than the ones not doing sport. Likewise, the job satisfaction level of the employees in this research varied according to the state of doing sport based on the variable of "The way the job provides for steady employment" (Item 8). The job satisfaction levels of the employees doing sport were found higher than those who did not. This result can be considered as the outbreak of the opinion of individuals working in a sports-based organization to guarantee the job security partly by participating in sportive activities. One of the personal factors affecting job satisfaction is educational background.

The job satisfaction levels of high school and associate degree graduates were found high in terms of the state of job's keeping busy (Item 1) and working conditions (Item 16). Likewise, Smith (2007) also reported that the employees with high level of education had low level of job satisfaction. This case shows that job satisfaction levels may vary according to whether the employees have jobs in accordance with their education levels. The job satisfaction levels of the high school graduates were found high in terms of the expressions "The competence of the supervisor in making decisions" (item 6), "The chance to do something that makes use of their abilities" (item 11), "The pay and the amount of work done"(item 13), "The chances for advancement" (item 14), " The way co-workers get along with each other " (item 17), and "being appreciated" (item 18). Based on these findings, it can be thought that a more positive attitude towards the manager can be seen as the education level decreases. Why the high school graduates are satisfied with their wages can be explained by the view that they are aware they work with a good wage compared to other education levels in today's conditions. 
Whereas it increases the job satisfaction of the high school graduates that they always have the promotion opportunity despite the training they received, it can be indicated as a reason for the dissatisfaction of the graduates of bachelor's degree and above. The organizational communication among the high school graduate employees in the study seems to be at a good level. What motivates the employees easily in line with the objectives of the institution by increasing trust among them is substantially that the communication channel within the organization is constantly open. The education level of the employees of the institution may not have an impact in increasing job satisfaction based on in-house communication. It seems that high school graduates have more job satisfaction about the reinforcement and rewarding of positive behavior in comparison with associate degree and bachelor's degree or higher.

Many studies in the literature report that job satisfaction levels vary in favor of high-income groups (Kuo and Chen, 2004; Rayton, 2006). It was seen in this study that the job satisfaction level of the two groups with high-income (1001-2000 and> 2001) were higher in terms of "The way the job provides for steady employment" (Item 8), "The pay and the amount of work done" (Item 13) and "The chances for advancement "(Item 14). Therefore, the higher the wages are the higher the satisfaction is (Kolasa, 1969). On the other hand, the low level of income of employees may have an impact which increases their concems about the future and lowers their job satisfaction. This also reveals the reason why the employees become unable to get satisfied with their work. It is thought that the promotion opportunity as well as the wages raises the social status of the employee and increases job satisfaction in addition to enhancing financial income earned from the work.

\section{CONCLUSION AND RECOMMENDATION}

This study reveals that the job satisfaction level of the employees is high in terms of the relationships with the other employees. Job satisfaction of employees is extremely important in terms of corporate performance. However, job satisfaction level of the employees was not found enough in tems of the opinions about the managers and being appreciated as deserved. It is thought that this situation results from the authority-responsibility confusion or conflict due to too many hierarchical levels in the institution. On the other hand, satisfaction levels of the employees were also found low in terms of wages and promotion. In addition, the employees' satisfaction level on the pay and the amount of work done decreased as their education level increased and job satisfaction levels tended to increase as their ages increased. Based on all these;

1. Wages should be given fit for the education level and the work of the employee and a fair pricing policy among the employees should be followed

2. The employee should be provided the chances for advancement which are evenhanded and fit for the performance of the employees and this should be used as a motivating factor

3. Hierarchical order should be well-established and subordinate employees should be given the impression that they are important for the institution by the superiors by consulting them when making decisions

4. Managers should be well selected and institutionalized and democratic working environment should be created in the institutions.

\section{REFERENCES}

[1] Akpinar, S. 2010. A research on the social skills, job satisfactions and problem-solving capabilities of the employees working in sports federations. Gazi University Institute of Health Sciences, PhD Thesis. Ankara.

[2] Aksu, G., Acuner, A.M., Tabak, R.S. 2002. A research on the job satisfaction of the administrators of central and provincial organizations of the ministry of health (Ankara sample). Journal of Ankara University Medical Faculty, 55 (4), 271-282.

[3] Baycan, A. 1985. An analysis of several aspects of job satisfaction between different occupational groups. Bogazici University, Istanbul.

[4] Bos, J.T., Donders, N.C.G.M., Bouwman-Brouwer, K.M., Van der Gulden, J.W.J. 2009. Work characteristics and determinants of job satisfaction in four age groups: University employees' point of view. International Archives of Occupational and Environmental Health, 82(10): 1249-1259.

[5] Burris, V. 1983. The social and political consequences of overeducation. American Sociological Review, 48(4): 454467.

[6] Chen, Y. 2007. Relationships among service orientation, job satisfaction and organizational commitment in the international tourist hotel industry. Journal of American Academy of Business, 11(2): 71-82.

[7] Erdem, R., Rahman, S., Avcı, L., Göktaş, B., Şenoğlu, B., Fıra,t G. 2008. Investigating job satisfaction and bumout levels of the persons working for the hospitals at city center of Elazığ, Turkey. Journal of Applied Sciences Research, 4(2): 188-201.

[8] Hurd, A.R., Barcelona, R.J., Meldrum, J.T. 2008. Leisure services management. Champaign, IL: Human Kinetics.

[9] Kolasa, B.J., 1969.Introduction to behavioral sciences for businesses. Translation Kemal Tosun. Istanbul: Istanbul University Business Adminis tration Faculty. 
[10] Kuo, Y., Chen, L. 2004. Individual demographic differences and job satisfaction among information technology personnel: An empirical study In Taiwan. International Journal of Management, 21(2): 221-231.

[11] McKenna, E. 2006. Business psychology and organizational behavior (4th ed.). New York: Psychology Press.

[12] McShane, S.L., Steen, S. 2009. Canadian organizational behavior (7th ed.). New York: McGraw-Hill.

[13] Rayton, B.A. 2006. Examining the interconnection of job satisfaction and organizational commitment: An application of the bivariate probit model. International Journal of Human Resource Management, 17(1): 139-154.

[14] Schultz, D.P., Schultz, S.E. 1998. Psychology and industry today. An Introduction to Industrial and Organizational Psychology. Macmillan Publishing Company, New York, USA.

[15] Smith, T.W. 2007. Job satisfaction in america: trends and socio-demographic correlates. Retrieved from http://wwwnews .uchicago.edu/releas es/07/pdf/070827.jobs.pdf

[16] Sünter, A.T., Canbaş, S., Dabak, Ş., Öz, H., Pekşen, Y. 2001. Exhaustion, work-related stress and job satisfaction levels of practitioners. General Medical Joumal. 16 (1).

[17] Ünsar, S., Taştan, İ., Ünsar, S., Dindar, İ. 2006. Job satisfaction levels and influencing factors: a field research in the health sector. Verimlilik Journal. (2): 131-134.

[18] Volkwein, J.F., Zhou, Y. 2003. Testing a model of administrative job satisfaction. Research in Higher Education, 44: 149-171.

[19] Weiss, D.J., Dawis, R.V., England, G.W., Lofquist, L.H. 1967. Manual for the minnesota satisfaction questionnaire. minnesota studies in vocational rehabilitation, Minneapolis: University of Minnesota, Industrial Relations Center. Vol. 22.

[20] Wilson, B., Squires, M., Widger, K., Cranley, L., Tourangeau, A. 2008. Job satisfaction among a multigenerational nursing workforce. Joumal of Nursing Management, 16: 716-723.

[21] Yelboğa, A. 2008. Analyzing the differences in job satisfactions of employees in the human resources department, Management. (19) 61:125-142 